\title{
Rare Plants of Bryce Canyon National Park, Utah
}

\author{
FREDERICK J. PEABODY $\downarrow$ DEPARTMENT OF BIOLOGY \\ UNIVERSITY OF SOUTH DAKOTA • VERMILLION
}

\section{- SumMaRY OF ReSEARCH PROJECT ACCOMPLISHMENTS}

\section{REFINEMENT OF LIST OF RARE AND POTENTIALLY RARE PLANTS IN BRYCE CANYON NATIONAL PARK}

A literature survey has been completed in order to determine plant species that have been considered rare, and also plant species that are potentially rare. Dr. Stan Welsh of the Botany and Range Science Department of Brigham Young University (Provo, Utah) was contacted personally during the field season. His experience in the region has provided a list of additional species that are considered rare for the state of Utah and occur on specific sites near the National Park (Table 1). It is possible that these additional rare species may occur within the boundaries of the park.

\section{DETERMINE DISTRIBUTION AND \\ ABUNDANCE OF RARE PLANT SPECIES IN BRYCE CANYON NATIONAL PARK}

Plant records of the small herbarium in the park were consulted and notation was made of the location and date of collection of each rare plant specimen.

Plant -records of the research herbarium at Brigham Young University were consulted and notation was made of the location and date of collection of each rare plant specimen. Special arrangements have been made with the curator (Kay
Table 1. List of additional rare plant species possibly found within park boundaries. (According to Welsh, S.L. personal communication).

1. Astragalus limnocharis var. tabulaeus

2. Cymopterus minimus

3. Eriogonum aretoides

4. Eriogonum panguicense var. panguicense

5. Lepidium montanum var. neeseae

6. Oxytropis oreophila var. jonesii

7. Physaria chambersii var. sobolifera

8. Ranunculus acris var. aestivalis

9. Spiranthes diluvialis

10. Heterotheca jonesii

Thorne) to obtain large format photocopies of each herbarium sheet for future reference.

Known locations of rare plant populations were visited in the park during the field work phase of the project. This included four weeks in June and two weeks in August. Five of the six species previously listed as rare were found in the park (Table 2), some at numerous locations. The sixth species is commonly found in the central and southern portion of the park, a region that is scheduled for plant survey during a subsequent field season.

Relative abundance of each of the five rare species found in this season's field work (Table 2) indicates that some are more rare than others. 
Table 2. List of rare plant species located in first field season.

Name

Number of

Relative

Abundance

Plots

Category 1 and 2 species:

1. Castilleja parvula var. revealii

2. Cryptantha ochroleuca

3. Pediomelum pariense

0.2282

4. Penstemon bracteatus

5. Silene petersonii var. minor

2

8

5

0.4601

Additional rare species:

6. Townsendia montana var. minima 5

7. Oxytropis oreophila var. jonesii

2

0.5150

* Estimates based on measured plant densities in individual plots.

Geographic location of populations of each of the five rare species found in this season's field work (Table 2) indicates that they are very closely correlated with edaphic factors, primarily substrate parent material. It is also noted that some of the species are commonly found along, and even on, heavily used trails. This may have some impact on management decisions relating to trail expansion and alternative trail usage patterns.

\section{CHARACTERIZE HABITAT PARAMETERS OF RARE PLANT POPULATIONS IN BRYCE CANYON NATIONAL PARK}

Field notations were made on each rare plant population to determine temporal, edaphic, topographic, and biotic components. Phenology, soil parent material, root substrate material, aspect of slope, percent of slope, and associated species were noted for each rare plant population.

\section{DEVELOP A LONG-TERM MONITORING PROGRAM FOR RARE PLANT POPULATIONS IN BRYCE CANYON NATIONAL PARK}

Permanent plots have been established for each rare plant population. The relative abundance of rare plants in each plot has been measured. This will provide a means of tracking the general health of rare plant populations through time.

\section{SIGNIFICANT FINDINGS}

A. Five of the six rare plant species were found in localities where they had been previously collected (Table 1). A preliminary search for the sixth rare species was not successful, but a more detailed survey is planned for the next two field seasons.

B. Permanent plots have been established for all of the five rare plant populations found (Table 2). From preliminary surveys it is possible that some of the species previously considered to be rare are more abundant than originally estimated.

C. Appropriate habitat may exist for inclusion in the rare plant listing of additional species that are found in regions of similar habitat outside of the National Park boundaries.

D. From preliminary surveys it is possible that rare plant populations are restricted to areas of the park that are currently experiencing very heavy use from foot and horse traffic. Attempts to locate rare plant populations at some distance from these areas has been unsuccessful. Continued surveys in more remote regions of the park may uncover additional rare plant populations.

\section{- PRoblems that IMPEDE PERFormanCe AND CORRECTIVE ACTIONS}

A. Dates of flowering times recorded on herbarium labels of rare plant species has proven to be an inaccurate predictor of primary anthesis. The variation of phenology at higher elevations is too 
great to be accurately predictable. One of the rare plant populations was sampled slightly past its primary anthesis. This may have made it more difficult to locate additional populations since the showy perianth is the primary search pattern. Adjusting the time of the field season (from four weeks in June to two weeks in June and two weeks in July) should allow researchers to sample rare plant populations when they are most conspicuous. This would be mediated by the lateness of the onset of spring temperatures.

B. Because of the ruggedness of the terrain, locating rare plant populations at some distance from established trails will involve more backpacking time and more preliminary detailed mapping. It was hoped that maps produced by the G.I.S. would be able to provide better predictors of potential areas of rare plant populations. Since the G.I.S. is currently undergoing reorganization is was not possible to obtain the needed maps. We hope that G.I.S. maps will be available during the next two field seasons so that backcountry search time can be as efficient as possible. Lacking G.I.S. maps researchers will use standard 7.5 minute topographic quadrangles.

\section{- WORK TO BE PERFORMED DURING ReMaining RePORTING PERIOD}

A. Data from all plots and all species will be compiled in order to determine the current status of the distribution of each rare plant species in the park.

B. Abundance measures and cover class values for each species will be computed.

C. Lists of edaphic, topographic, and biotic determinants for each rare plant species will be compiled.

D. Park habitats, as indicated on topographic maps and preliminary G.I.S. maps, will be evaluated for the possible occurrence of rare plant populations. A list of potential new localities will be compiled for survey attempts during the next two field seasons. 